\title{
Consumption of Water-Soluble Egg Yolk Extract on Growth Rate, Changes in Blood Cholesterol Levels, and Immune Modulation in BALB/c Mice
}

\author{
Won-Young Lee, Ran Lee, Hee-Chan Kim, Kyung-Hoon Lee, Kyung Sook Noh, Hyoun Wook Kim¹, \\ Ji-Hyuk Kim ${ }^{1}$, Dong-Uk Ahn², In-Surk Jang ${ }^{3}$, Aera Jang ${ }^{4}$, Hoon-Taek Lee ${ }^{5}$ and Hyuk Song* \\ Division of Food Bioscience, Research Institute for Biomedical \& Health Science, \\ Konkuk University, Chung-ju 380-701, Korea \\ ${ }^{\prime}$ National Institute of Animal Science, RDA, Suwon 441-706, Korea \\ ${ }^{2}$ Department of Animal Science, Iowa State University, Iowa 50011, USA \\ ${ }^{3}$ Department of Animal Science \& Biotechnology, \\ Gyeong-Nam National University of Science \& Technology, Jin-ju 660-758, Korea \\ ${ }^{4}$ Department of Animal Product \& Food Science, Kangwon National University, Chuncheon 200-701, Korea \\ ${ }^{5}$ Department of Animal Biotechnology, Konkuk University, Seoul 143-701, Korea
}

\begin{abstract}
Egg consumption has been limited to avoid cardiovascular diseases such as atherosclerosis and hyperlipidemia, because the yolk contains high levels of cholesterol. This study was conducted to evaluate the effect of the water-soluble component of egg-yolk on the growth efficiency, immune modulation, and changes in serum lipid levels in BALB/c mice. A total $5 \mathrm{wk}$ old $120 \mathrm{BALB} / \mathrm{c}$ male mice were divided into 4 groups and were fed $0,2,10$, and $20 \mathrm{mg} / \mathrm{d}$ water-soluble egg yolk extract (WSEYE) for $5 \mathrm{wk}$. Water-soluble egg yolk extract (WSEYE) uptake resulted in a significant reduction in daily weight gain and feed efficiency rate (FER). The mouse groups treated with 2 and $20 \mathrm{mg} / \mathrm{d}$ WSEYE showed a significant increase in populations of monocytes at the third wk and B-lymphocyte activity at the fifth wk. In addition, WSEYE uptake did not influence serum immunoglobulin E levels. In serum lipid-profile studies, treatment of WSEYE did not alter total cholesterol and low-density lipoprotein levels; however, blood triglyceride levels were significantly diminished in mice treated with $2 \mathrm{mg} / \mathrm{d}$ at the third wk $(p<0.05)$, and the level of high-density lipoprotein was significantly increased in the mice group treated with 2 and $10 \mathrm{mg} / \mathrm{d}$ WSEYE after $5 \mathrm{wk}(p<0.05)$. Taken together, the data demonstrate the beneficial effects of WSEYE in the diet on immune modulation and serum lipid profiles in mouse models; therefore, this study suggests that ingestion of water-soluble fraction of egg yolk might not be related to the increased risk of heart disease, but can be an excellent candidate for maintaining health.
\end{abstract}

Key words: water-soluble egg yolk extract (WSEYE), cholesterol, immunoglobulin, lymphocyte activation

\section{Introduction}

The chicken egg has been known to be the perfect food that contains many nutrients, including essential amino acids, unsaturated fatty acids, folate, vitamins, and minerals (Song et al., 2000). However, for most of the past 40 years, large amount of daily egg consumption by men was limited because egg yolk contains high levels of cholesterol. Elevated low-density lipoprotein cholesterol (LDL-C) levels are a major risk factor for coronary heart disease (CHD). Dietary cholesterol often raises blood

*Corresponding author: Hyuk Song, Division of Food Bioscience, Konkuk University, Chung-ju 380-701, Korea. Tel: 82-43-8403522, Fax: 82-43-842-3522, E-mail: lovelyhusband@kku.ac.kr
LDL-C levels in human (Stamler et al., 1998). However, data from free-living populations show that egg consumption is not associated with higher cholesterol levels (Kritchevsky and Kritchevsky, 2000). Furthermore, epidemiological literature does not support the idea that egg consumption is a risk factor for CHD. Therefore, the most recent American Heart Association guidelines no longer include a recommendation to limit egg consumption (Kritchevsky, 2004).

Recently, biophysiological functions of the chicken embryo extract that were reported using in vitro cultured cell models indicated that the extracts enhanced spleen lymphocyte proliferation and interleukin-2 (IL-2) secretion, while peritoneal macrophage phagocytosis and nitric oxide (NO) production activity were elevated (Li et al., 
2012). In addition, chicken egg yolk has been used as an inexpensive and effective source of immunoglobulin Y (IgY) for the treatment of various bacterial (Sunwoo et al., 2010) and viral (Wallach et al., 2011) infections in animals.

Despite of these beneficial effects of egg extracts, hen eggs are regarded as one of the most prevalent allergens that affect about $1.3 \%$ of infants $<3$ years of age in the US (Sampson, 2004). Although the allergic reactions are more frequently elicited by egg-white proteins than egg yolk (Anet et al., 1985), some LDLs such as apovitellenins I and VI in egg yolk act as allergens (Anet et al., 1985; Walsh et al., 1988).

Although egg extract has been shown to have either beneficial or detrimental biological effects, the effect of water-soluble components that are removed from lipid cholesterol of egg yolk on diet, blood cholesterol levels, and immune modulation in normal healthy animal models has not yet to be clarified. In the present study, different concentrations of the water-soluble egg yolk extract (WSEYE) were supplied to mice to determine the correlation between WSEYE consumption and health parameters by measuring the changes in body weight, blood cholesterol level, sensitivity to allergy, and immunomodulatory activity, and the advantages and disadvantages of WSEYE consumption have been discussed.

\section{Materials and Methods}

\section{Preparation of WSEYE}

Commercially available normal fresh eggs were obtained from a local egg farm. The yolk was selected and the white was removed using 3M papers (GE Healthcare Life Science, USA). The egg yolk extraction method was modified from the previous report for extraction of watersoluble yolk components (Kim et al., 1999). Briefly, the selected egg yolk was $10 \%$ dilluted ( $v / v, 1$ volume of egg yolk : 9 volume of water) with distilled water and homogenized for $30 \mathrm{~min}$ in ice. The homogenized yolk mixture was centrifuged at $6,000 \mathrm{~g}$ for $30 \mathrm{~min}$ at $4^{\circ} \mathrm{C}$ to precipitate insoluble yolk components. The water-soluble materials contained supernatant was freeze-dried using a freeze dryer (Ilshintech, Korea) and resuspended in phosphatebuffered saline (PBS) solution.

\section{Animals}

A total 5 wk old 120 male BALB/c mice (Nara Biotech Co., Korea) were housed in a conventional temperatureand humidity-controlled room and provided standard lab- oratory food and water. All animal care protocols were approved by the Konkuk University Institutional Animal Care and Use Committee (IACUC; approval No.: KU130 37).

\section{Group design and experiment}

Four groups of mice (10 mice/group) were used in the study. Group 1 comprised animals that were treated with an oral dose of $1 \times$ PBS as a vehicle for $5 \mathrm{wk}$. Groups 2, 3 , and 4 comprised animals that were treated with an oral dose of 2, 10, and $20 \mathrm{mg} / \mathrm{d}$ of WSEYE, respectively, dissolved in $1 \times$ PBS for $3 \mathrm{~d}$ a week for $5 \mathrm{wk}$. The changes in body weight (BW) and the average feed intake of the mice were measured every $7 \mathrm{~d}$ during WSEYE treatment.

\section{Lymphocyte and serum preparation}

Ten mice from each experimental group were sequentially anesthetized using $2.5 \%(v / v)$ avertinon $0,7,21$, and $35 \mathrm{~d}$ of the experimental period, and total blood samples were collected through direct heart puncture. Approximately $1 \mathrm{~mL}$ of blood was collected into tubes containing ethylenediaminetetraacetic acid (EDTA) (Becton Dickinson, USA), and then $0.5 \mathrm{~mL}$ of whole blood was mixed with $0.5 \mathrm{~mL}$ of Histopaque-1077 (Sigma-Aldrich, USA) and centrifuged at $1,200 \mathrm{~g}$ for $20 \mathrm{~min}$. The lymphocyte cells were carefully isolated from the middle of the gradient. To separate the serum, $0.5 \mathrm{~mL}$ of whole blood was incubated for $1 \mathrm{~h}$ at room temperature, the samples were centrifuged at $1,200 \mathrm{~g}$ for $15 \mathrm{~min}$, and the supernatant was carefully collected and stored at $-70^{\circ} \mathrm{C}$.

\section{Blood cell analysis}

The collected whole-blood samples were inverted several times to prevent coagulation in an EDTA-coated tube. The concentration of mice white blood cells (WBCs) and the percentages of neutrophils, lymphocytes, eosinophils, basophils, and monocytes were compared among the four different treatments. Samples were measured immediately on a Hema Vet 850 (CDC Technologies, UK) analyzer, according to the manufacturer's instructions.

\section{Measurement of lymphocyte activation during WSEYE treatment}

Isolated lymphocytes $\left(5 \times 10^{5}\right.$ cells $)$ from each treated group were plated on a 96-well plate and incubated for $1 \mathrm{~h}$ at $37^{\circ} \mathrm{C}$. Lipopolysaccharide (LPS, $2.5 \mu \mathrm{g} / \mathrm{mL}$ ) was added to cultured cells to identify B-lymphocyte activity, and $2.5 \mu \mathrm{g} / \mathrm{mL}$ concavalin A (ConA) was added to assess T-lymphocyte activity. Cells were then incubated for an 
additional $48 \mathrm{~h}$. Cell viability and proliferation were analyzed using an EZ-cytotox kit (Daeil Lab Service, Korea), according to the manufacturer's instructions. The cell proliferation rate was then determined on the basis of the absorbance at $550 \mathrm{~nm}$ by using a Sunrise microplate reader (Tecan Austria GmbH, Austria).

\section{Analysis of immunoglobulin}

The immunoglobulin $\mathrm{G}$ ( $\mathrm{IgG}$ ) and immunoglobulin $\mathrm{E}$ (IgE) concentrations in the total blood samples were measured using a mouse IgG and IgE enzyme-linked immunosorbent assay (ELISA) Quantitation Kit (Bethyl Laboratory Inc., USA), according to the manufacturer's instructions. Briefly, anti-mouse $\operatorname{IgG}$ and $\operatorname{IgE}(1 \mu \mathrm{g}$ each) antibodies were diluted using $100 \mu \mathrm{L}$ of the coating buffer and incubated for $1 \mathrm{~h}$ on 96-well plates. The non-binding excess antibodies were then aspirated, and the plates were washed 3 times with the washing solution. The blocking solution was added, and the samples were incubated for $30 \mathrm{~min}$; then, $100 \mu \mathrm{L}$ of the reaction mixture was added to the samples, which were then incubated for an additional $1 \mathrm{~h}$. The samples were then washed 5 times with the washing solution. Horseradish peroxidase (HRP)-conjugated secondary antibodies were added, and the samples were incubated for $1 \mathrm{~h}$ at room temperature. The HRP solution was then removed, and the samples were washed 5 times with the washing solution. 3,3',5,5'-Tetramethylbenzidine (TMB) solution $(100 \mu \mathrm{L} /$ well) was added, and the samples were incubated for $20 \mathrm{~min}$ at room temperature. Finally, $100 \mu \mathrm{L}$ of $\mathrm{H}_{2} \mathrm{SO}_{4}$ was added, and the concentration of each Ig was determined on the basis of the absorbance at $450 \mathrm{~nm}$ by using the microplate reader. Determination of the concentration of $\operatorname{IgG}$ and $\operatorname{IgE}$ in serum was evaluated by the comparison with concentrations of serial dilutions of each IgG and IgE standard proteins provided from the kit.

\section{Analyses of cholesterols and lipids}

Total cholesterol (TC) and triglyceride (TG) concentrations were determined enzymatically using the cholesterol oxidase-phenol aminophenazone (CHOD-PAP) and lipase/glycerol-3-phosphate oxidase (GPO)/PAP meth- ods, respectively, on a modular analytics (Roche, Basel, Switzerland). High-density lipoprotein cholesterol (HDLC) was subsequently measured by precipitation with phosphotungstic acid and $\mathrm{MgCl}_{2}$ (Roche, Basel, Switzerland). The LDL cholesterol (LDL-C) assay was performed according to the manufacturer's instructions on a modular analytics by using an LDL-C Plus $2^{\text {nd }}$ Generation kit (Roche, Switzerland).

\section{Statistical analysis}

One-way ANOVA was performed on calculations of the results by using GraphPad Prism $4^{\circledR}$ (GraphPad Software, Inc., USA) for Windows XP. Tukey's multiple comparison test was used for comparison between groups. All data from figures are expressed as mean $( \pm S D)$. The null hypothesis was rejected when the probability was $p<0.05$.

\section{Results and Discussion}

\section{Body weight gain, feed intake, and feed efficiency rate}

The BWs of mice were measured after WSEYE treatment with $0,2,10,20 \mathrm{mg} / \mathrm{d}$ for $5 \mathrm{wk}$ to ensure biosafety and changes of body weight. The dosages of WSEYE used in this study were determined by comparing the average BW of humans and 5-week-old mice $(60 \mathrm{~kg}$ and $20 \mathrm{~g}$, respectively). If humans ate one egg/d, $15 \mathrm{~g}$ of egg yolk would be consumed, and $15 \mathrm{~g}$ of egg-yolk consumption is approximately $5 \mathrm{mg}$ for a 20 -g mouse; therefore, treatment of 2, 10, and $20 \mathrm{mg} / \mathrm{d}$ WSEYE is equal to $1 / 2.5,2$, and 4 egg yolks consumed/d in mice. The daily BW gains in the control, 2,10 , and $20 \mathrm{mg} / \mathrm{d}$ WSEYE treatments were $0.150 \pm 0.034,0.105 \pm 0.021,0.140 \pm 0.036$, and $0.119 \pm 0.023 \mathrm{~g}$, respectively (Table 1$)$. The daily BW gain of the 2 and 20 $\mathrm{mg} / \mathrm{d}$ WSEYE-treated groups showed a significant decrease $(p<0.05)$ compared to that in the control; however, the $10 \mathrm{mg} / \mathrm{d}$ WSEYE-treated group did not show any significant change (Table 1). In the group treated with 10 $\mathrm{mg} / \mathrm{d}$ WSEYE, there was a significant increase in average feed intake for $5 \mathrm{wk}$ (Table 1); therefore, this significant increase appeared to have a correlation with an increase in feed intake. Analysis of the feed efficiency ratio (FER)

Table 1. Changes in daily body weight gain and daily feed intake in mice treated with water-soluble egg yolk extract

\begin{tabular}{ccccc}
\hline \hline Treat $(\mathrm{mg} / \mathrm{d})$ & 0 & 2 & 10 & 20 \\
\hline Weight gain $(\mathrm{g} / \mathrm{d})$ & $0.150 \pm 0.034$ & $0.105 \pm 0.021^{*}$ & $0.140 \pm 0.036$ & $0.119 \pm 0.023^{*}$ \\
Feed intake (g/d) & $3.251 \pm 0.124$ & $3.034 \pm 0.212$ & $4.040 \pm 0.553^{*}$ & $3.749 \pm 0.475$ \\
FER & 0.046 & 0.035 & 0.035 & 0.032 \\
\hline
\end{tabular}

$p$-value was detected in between $0 \mathrm{mg} / \mathrm{d}$ (control) and each WSEYE treatment for $5 \mathrm{wk}\left({ }^{*} p<0.05, \mathrm{n}=10\right)$. FER; feed efficiency rate. WSEYE; water-soluble eggyolk extract. 
showed a decrease in FER in all WSEYE-treated groups, compared to that in the control (Table 1). These data are also similar to the results of previous reports that an egg breakfast induced greater satiety and significantly reduced body weight in women (Vander Wal et al., 2005). Taken together, our data showed that WSEYE consumption did not reduce feed intake but did decrease daily weight gain and FER, and regular consumption of WSEYE might result in growth inhibition in normal healthy mice. This observation suggests that WSEYE could be a promising regulator for $\mathrm{BW}$.

\section{Changes in blood immune-cell populations and lymphocyte activation}

To investigate whether WSEYE can influence the population of blood immune cells, changes in the number of WBCs, granulocytes, and monocytes were analyzed. No significant differences in the populations of WBCs, lymphocytes, neutrophils, eosinophils, and basophils were identified among the treatment groups following the time courses (Figs. 1A-E). The percentage of monocytes was significantly increased in the $2 \mathrm{mg} / \mathrm{d}$ WSEYE-treated group at the third week (Fig. 1F). Interestingly, the populations of other immune cells were within the normal ranges; however, the average population of monocytes in the 10 and $20 \mathrm{mg} / \mathrm{d}$ WSEYE-treated groups at the first week, 2 and $10 \mathrm{mg} / \mathrm{d}$ WSEYE-treated groups at the third week, and 2 and $20 \mathrm{mg} / \mathrm{d}$ WSEYE-treated groups at the fifth week were over the normal range (Fig. 1F). Although the populations of lymphocytes were not changed among the different WSEYE-treated groups following the time courses, activation of $\mathrm{B}$ and $\mathrm{T}$ lymphocytes was compared among the control and WSEYE-treated groups. The effect of WSEYE $(20 \mathrm{mg} / \mathrm{d})$ on B-cell activation was significantly higher than that in the control groups; however, T-cell activity was neither increased nor decreased compared to that in the control group (Fig. 2). The increased number of monocytes and B-lymphocyte activation suggest a putative role for WSEYE in the proliferation of monocytes and activation of B lymphocytes. Blood monocytes are an important mediator of innate immunity and are likely to be differentiated into antigen-presenting cells (APCs) such as macrophages and dendritic cells in tissues (Cheong et al., 2010). In addition, lymphocytes are activated and controlled by APCs that differentiated from monocytes in lymph nodes (Ahrens et al., 2009; Cheong et al., 2010; Moussion and Girard, 2011); therefore, WSEYE can be involved in the activation of APC as an immune
A

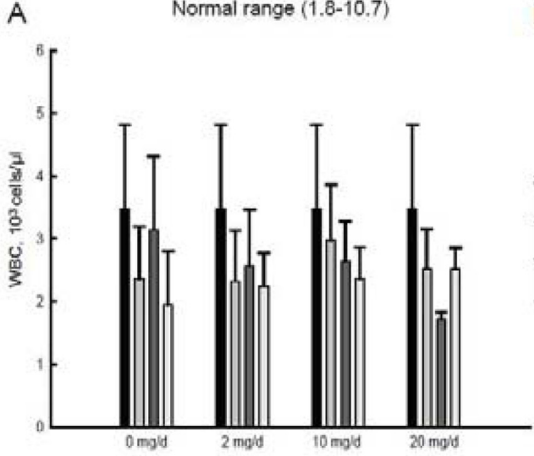

D

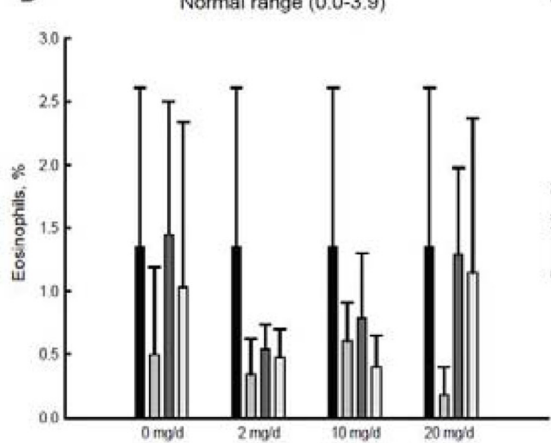

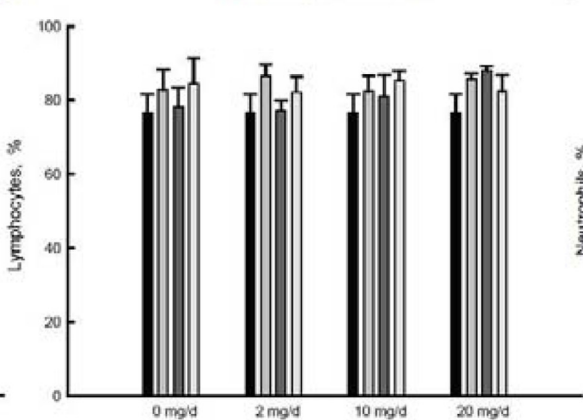

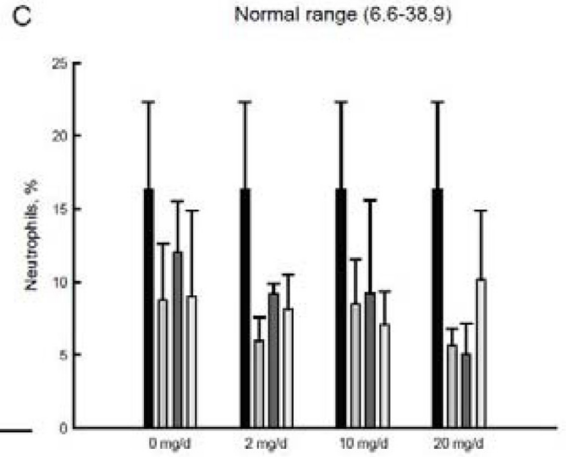

E

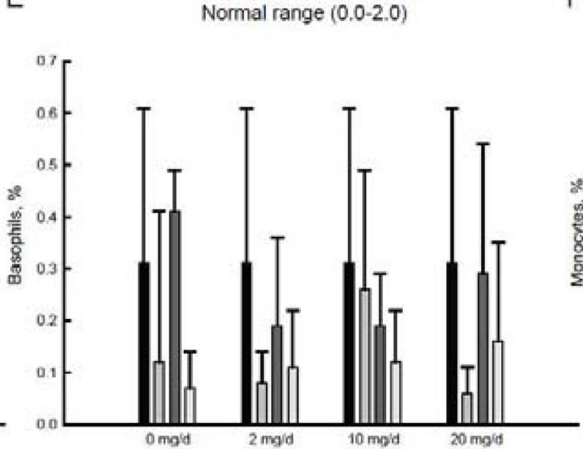

F

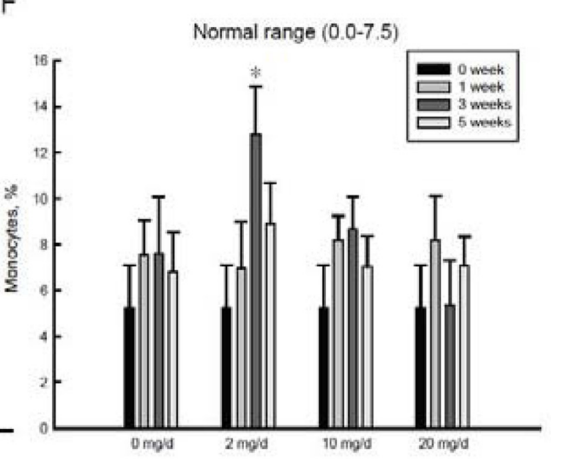

Fig. 1. Number of white blood cells (WBC), lymphocytes, granulocytes, and monocytes. (A) WBC and (B) lymphocytes are represented by the number of blood cells. (C) Neutrophils, (D) eosinophils, (E) basophils, and (F) monocytes are presented as percentages of blood cells. Statistical analysis was conducted between $0 \mathrm{mg} / \mathrm{d}$ (control) and each WSEYE treatment in the same week ( $\left.{ }^{*} p<0.05, n=10\right)$. WSEYE: water-soluble egg yolk extract 
A

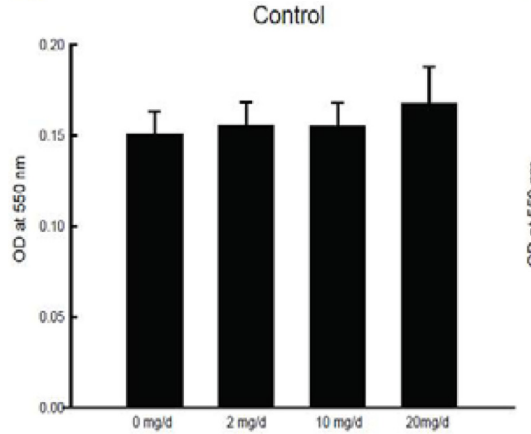

B

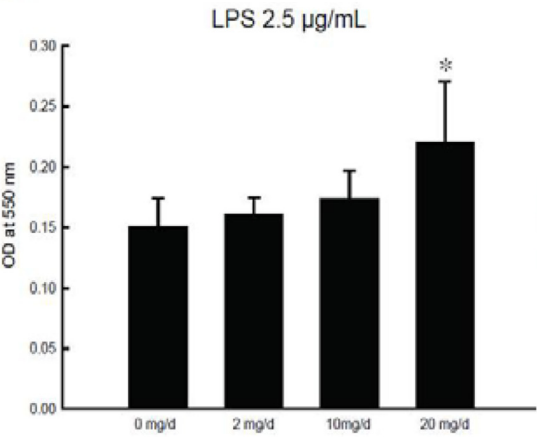

C

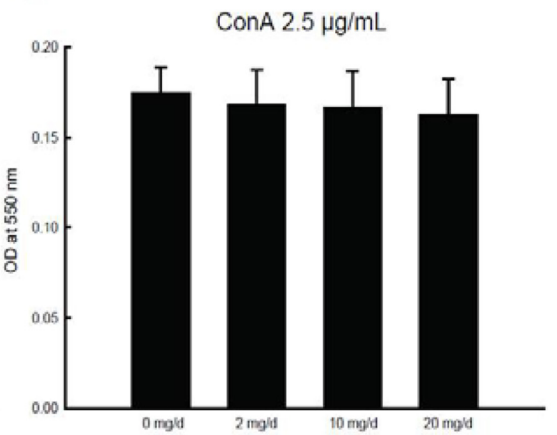

Fig. 2. B- and T-lymphocyte activation by water-soluble egg yolk extract. Lymphocytes were isolated from WSEYE (at 0, 2, 10, and $20 \mathrm{mg} / \mathrm{d})$-treated mice on week $0,1,3$, and 5 . Isolated lymphocytes $\left(5 \times 10^{5}\right.$ cells) were treated with (A) distilled water, (B) $2.5 \mu \mathrm{g} / \mathrm{mL}$ lipopolysaccharides (LPS) for B-cell activation, and (C) $2.5 \mu \mathrm{g} / \mathrm{mL}$ concavalin A (Con A) for T-cell activation. $p$-value was detected between $0 \mathrm{mg} / \mathrm{d}$ (control) and each WSEYE treatment at the fifth week $\left({ }^{*} p<0.05, \mathbf{n}=10\right)$. WSEYE: water-soluble eggyolk extract; OD: optical density

modulator, and these activated APCs might initiate lymphocyte activation in mice.

In addition, chicken-egg yolk has been known to be a source of $\operatorname{IgY}$ which is also a water soluble protein, and chicken-egg extracts were used for the treatment of various bacterial and viral infections in animals (Farrelly et al., 1992; Ikemori et al., 1992; Li et al., 2012). It can also be speculated that treatment with WSEYE might stimulate innate immunity by increasing the population of monocytes in the blood; therefore, treatment with WSEYE on animals that are infected with a bacterium or virus might increase both innate immunity by the stimulation of the monocyte population and passive immunity by increased IgY activity.

A

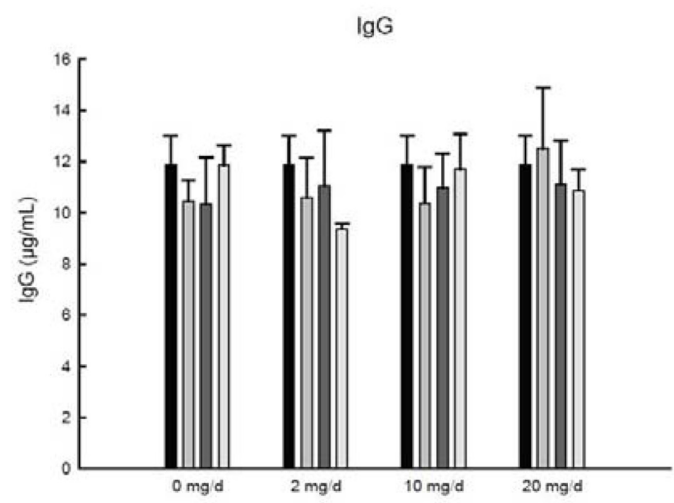

\section{Effect of WSEYE on immunoglobulin levels}

To determine the ability of WSEYE to modulate blood Ig levels in mice, IgG and IgE concentrations in the blood were analyzed at the fifth week of WSEYE treatment. No significant alteration in blood IgG concentration was observed in each WSEYE treatment group compared to that in the control (Fig. 3A). Blood IgE concentration was also not significantly altered among the treatment groups (Fig. 3). Egg allergy has been known to be the most common food allergy in children with atopic dermatitis (Niggemann et al., 1999). The food allergy is frequently the result of an IgE-mediated hypersensitivity reaction, and serum IgE level has a strong association with allergies (Burrows et al., 1989). Egg white contains several allergenic proteins, including ovomucoid, ovalbumin, ovotransferrin, lysozyme, and ovomucin (Heine et al., 2006).
B

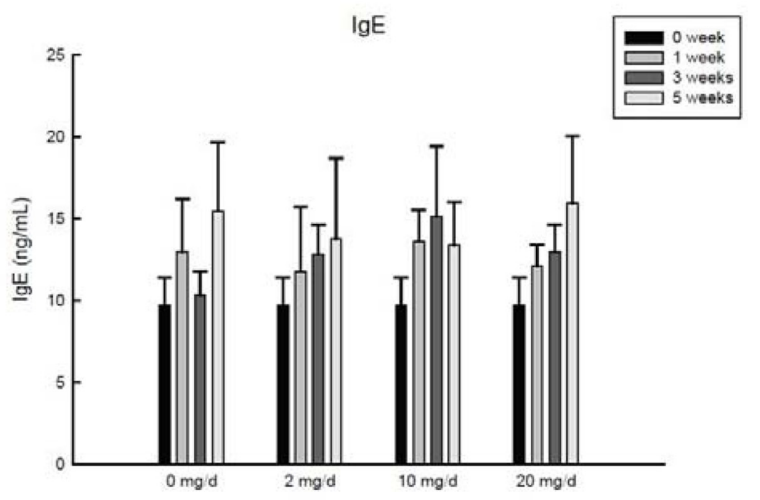

Fig. 3. Effect of water-soluble eggyolk extract treatment on mice immunoglobulin production. Blood samples were collected from WSEYE (at 0, 2, 10, and $20 \mathrm{mg} / \mathrm{d}$ )-treated mice on week 0, 1, 3, and 5. Samples were incubated with anti-mouse IgG (A) and IgE (B) antibodies. Horseradish peroxidase (HRP)-conjugated secondary antibody was used to detect the absorbance of each Ig. $p$-value was detected in between $0 \mathrm{mg} / \mathrm{d}$ (control) and each WSEYE treatment at the fifth week $\left({ }^{*} p<0.05\right.$, $\mathbf{n}=10)$.WSEYE: water-soluble eggyolk extract 
In addition, egg yolk alpha livetin is a major allergen in egg yolk; other allergens have been identified in egg yolk, including vitellinin and apoprotein B, although their role remains unclear (Szepfalusi et al., 1994). In this study, serum IgE levels were neither decreased nor increased in WSEYE-treated groups compared to those in the control group. Allergic reactions vary with individuals; some individuals do not have allergies to specific allergens that can induce an allergic reaction in sensitive individuals. Generally, healthy people show less sensitivity to allergens than immunologically unstable individuals. In this study, treatment of mice with WSEYEin different concentrations did not prompt allergic reactions in mice at ages 5 to $10 \mathrm{wk}$. At $5 \mathrm{wk}$ of age, male mice were similar to the post-pubertal stage of a male human, suggesting that consumption of egg yolk does not induce an allergic reaction in post-pubertal humans. It is necessary to develop efficient technology for reducing food allergies, such as heat processing (Coombs and McLaughlan, 1984), enzymatic hydrolysis (Van der Plancken et al., 2004), and gamma irradiation (Seo et al., 2004).

A

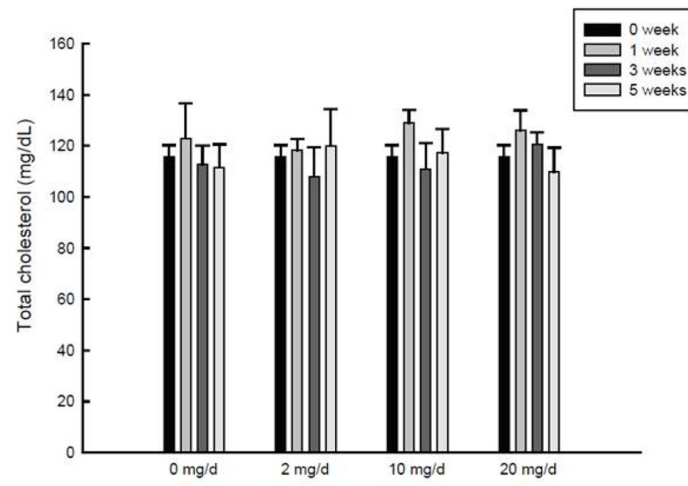

C

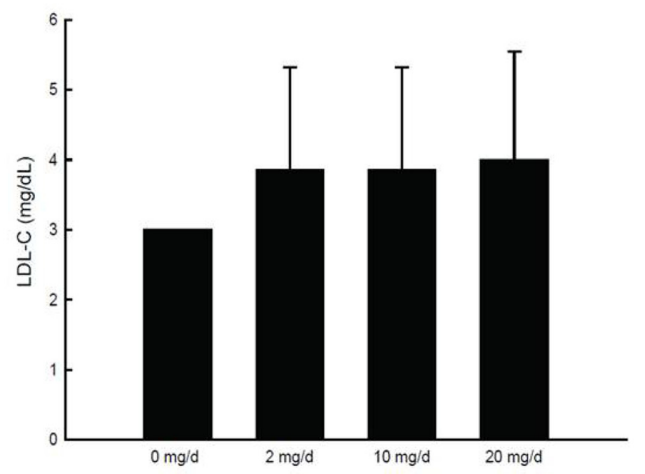

\section{Effect of WSEYE on serum lipid profile}

Serum lipid levels were identified following the ingestion of different concentrations of WSEYE (Fig. 4). The level of TC was not significantly changed among the treatment groups over the experimental periods (Fig. 4A), but the level of serum TG was significantly decreased in the $2 \mathrm{mg} / \mathrm{d}$ WSEYE-treated group at the fifth week (Fig. 4B). Although the intake of WSEYE did not affect LDL-C levels, it is remarkable that the level of HDL-C was significantly increased in the 2 and $10 \mathrm{mg} / \mathrm{d}$ WSEYE treated groups after $5 \mathrm{wk}$ (Figs. 4C and D). Because egg contains approximately $210 \mathrm{mg}$ of TC, the recommended egg consumption was limited to 3 eggs/wk, which is about 300 $\mathrm{mg}$ of TC/d, to prevent heart disorders (AHA, 1973). Previous report suggests dietary cholesterol raises levels of total and LDL-cholesterol that promote coronary heart disease (Hu et al., 1999). However, many researchers refuted that the intake of dietary cholesterol does not increase blood cholesterol levels (Clark et al., 1997; Howell et al., 1997; Krumholz et al., 1994), because intake of dietary cholesterol induced a decrease in internal cho-

B

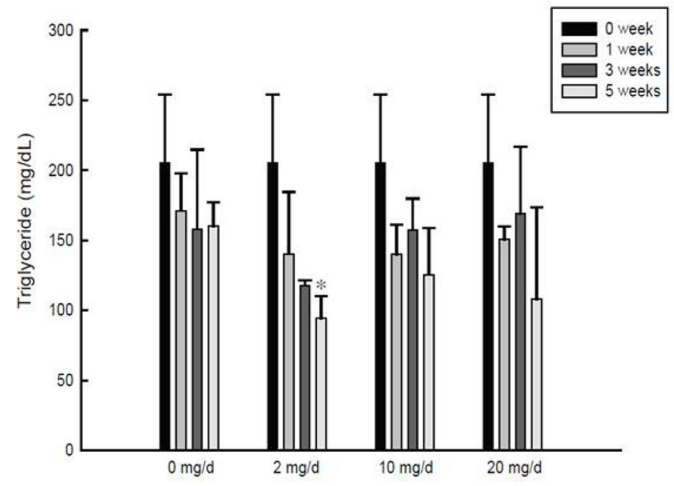

D

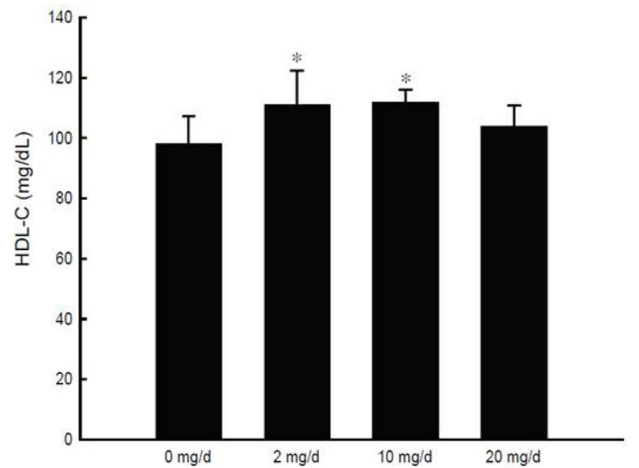

Fig. 4. Changes in serum lipid profiles by water-soluble egg yolk extract treatment. $P$-value for (A) total cholesterol (TC) and (B) triglycerides were detected between $0 \mathrm{mg} / \mathrm{d}$ (control) and each WSEYE treatment in the same week $\left({ }^{*} p<0.05, \mathrm{n}=10\right) . P$ value for (C) low-density lipoprotein cholesterol (LDL-C) and (D) high-density lipoprotein cholesterol (HDL-C) were detected between $0 \mathrm{mg} / \mathrm{d}$ (control) and each WSEYE treatment at the fifth week $\left({ }^{*} p<0.05, \mathrm{n}=10\right)$. WSEYE: water-soluble egg yolk extract. 
lesterol synthesis in the liver and the conversion of the internal cholesterol to bile acid, which is excreted (McNamara, 2000). Supporting these previous reports, the $2 \mathrm{mg} / \mathrm{mL}$ WSEYE-treated mice did not show an increase in TC but a decrease in TG. These data are in accordance with previous reports that a high cholesterol diet decreased he- patic TG levels but increased the level of fecal TG (Jang et al., 2011). Chicken egg yolk also contains lecithin and sphingomyelin that controls the blood cholesterol levels by inhibiting the reuptake of bile acid (Eckhardt et al., 2002; Jiang et al., 2001; Nagaoka et al., 2002; Noh and Koo, 2003). In this aspect, we assume that WSEYE contained mostly water-soluble components that are livetin, IgY, unknown peptides, amino acids, carbohydrates, and vitamin, etc. Therefore, it is possible that WSEYE contains cholesterol-regulating materials that might inhibit the increase of TC levels and decrease the TG levels in mice. In addition, a significant increase HDL-C in the 2 and $10 \mathrm{mg} / \mathrm{d}$ WSEYE-treated groups were also remarkable, because HDL-C is known to eliminate blood cholesterol to prevent atherosclerosis and hyperlipidemia. Taken together, the intake of WSEYE does not show an increase in serum cholesterol levels, whereas it decreases TG and increases HDL-C; this suggests that WSEYE has a positive effect on regulating serum lipid levels.

\section{Conclusion}

This study was designed to investigate the physiological effect of water-soluble components of egg yolk extract on mice. The present results suggested that consumption of WSEYE decreased FER, daily weight gain and level of $\mathrm{TG}$, but increase of monocyte population in WBC, activity of B lymphocytes and level of HDL-C. Therefore, WSEYE may not only have an important role in weight control, but also have a role in regulating physiological process in immune and cardiovascular system.

\section{Acknowledgements}

This work was carried out with the support of the Cooperative Research Program for Agriculture Science \& Technology Development (Project No. PJ008460), Rural Development Administration, Republic of Korea.

\section{References}

1. American Heart Association (AHA) (1973) Diet and Coro- nary Heart Disease. Dallas: American Heart Association.

2. Ahrens, B., Gruber, G. C., Rha, R. D., Freund, T., Quarcoo, D., Awagyan, A., Hutloff, A., Dittrich, A. M., Wahn, U., and Hamelmann, E. (2009) BCG priming of dendritic cells enhances $\mathrm{T}$ regulatory and Th1 function and suppresses allergeninduced Th2 function in vitro and in vivo. Int. Arch. Allergy. Immunol.150, 210-220.

3. Anet, J., Back, J. F., Baker, R. S., Barnett, D., Burley, R. W., and Howden, M. E. (1985) Allergens in the white and yolk of hen's egg. A study of IgE binding by egg proteins. Int. Arch. Allergy Appl. Immunol. 77, 364-371.

4. Burrows, B., Martinez, F. D., Halonen, M., Barbee, R. A., and Cline, M. G. (1989) Association of asthma with serum IgE levels and skin-test reactivity to allergens. N. Engl. J. Med. 320, 271-277.

5. Cheong, C., Matos, A., Choi, J. H., Dandamudi, D, B., Shrestha, E., Longhi, M, P., Jeffrey, K, L., Anthony, R, M., Kluger, C., Nchinda, G., Kho, H., Rodriguez, A., Idoyaga, J., Pack, M., Velinzon, K., Park, C, G., and Steinman, R, M. (2010) Microbial stimulation fully differentiates monocytes to DCSIGN/CD209+ dendritic cells for immune T cell areas. Cell 143, 416-429.

6. Clarke, R., Frost, C., Collins, R., Appleby, P., and Peto, R. (1997) Dietary lipids and blood cholesterol: Quantitative metaanalysis of metabolic ward studies. Brit. Med. J. 314, 112117.

7. Coombs, R. R. and McLaughlan, P. (1984) Allergenicity of food proteins and its possible modification. Ann. Allergy 53, 592-596.

8. Eckhardt, E. R., Wang, D. Q., Donovan, J. M., and Carey, M. C. (2002) Dietary sphingomyelin suppresses intestinal cholesterol absorption by decreasing thermodynamic activity of cholesterol monomers. Gastroenterol. 122, 948-956.

9. Farrelly, C. O., Branton, D., and Wanke, C. A. (1992) Oral ingestion of egg yolk immunoglobulin from hens immunized with an enterotoxigenic Escherichia coli strain prevents diarrhea in rabbits challenged with the same strain. Infect. Immun. 60, 2593-2597

10. Heine, R. G., Laske, N., and Hill, D. J. (2006) The diagnosis and management of egg allergy. Curr. Allergy Asthma. Rep. 6, 145-152

11. Howell, W. H., McNamara, D. J., Tosca, M. A., Smith, B. T., and Gaines, J. A. (1997) Plasma lipid and lipoprotein responses to dietary fat and cholesterol: a meta-analysis. Am. J. Clin. Nutr. 65, 1747-1764.

12. Hu, F. B., Stampfer, M. J., Rimm, E. B., Manson, J. E., Ascherio, A., Colditz, G. A., Rosner, B. A., Spiegelman, D., Speizer, F. E., Sacks, F. M., Hennekens, C. H., and Willett, W. C. (1999) A prospective study of egg consumption and risk of cardiovascular disease in men and women. JAMA 281, 1387-1394.

13. Ikemori, Y., Kuroki, M., Peralta, R. C., Yokoyama, H., and Kodama, Y. (1992) Protection of neonatal calves against fetal enteric colibacillosis by administration of egg yolk powder from hens immunized with k99-piliated enterotoxigenic $E s$ cherichia coli. Am. J. Vet. Res. 53, 2005-2008. 
14. Jang, A., Kim, D. W., Park, J. E., Choe, J. H., Kang, K. H., Ham, J. S., Oh, M. H., Seol, K. H., Lee, S. K., Kim, D. H., Kim, H. W., Hwang, K. H., Hwang, Y. J., and Kim H. K. (2011) Effect of hen egg supplementation on blood lipid profile and fecal bile acid of C57BL/6 mouse fed normal and high cholesterol diet. Korean J. Food. Sci. An. 31, 250-256.

15. Jiang, Y., Noh, S. K., and Koo, S. I. (2001) Egg phosphatidylcholine decreases the lymphatic absorption of cholesterol in rats. J. Nutr. 131, 2358-2363.

16. Kim, I. H., Lee, Y. T., Lee, C. H., and Chung, B. H. (1999) Purification of egg immunoglobulin IgY. Korean J. Biotechnol. Bioeng. 14, 677-981.

17. Kritchevsky, S.B. and Kritchevsky, D. (2000) Egg consumption and coronary heart disease: An Epidemiologic Overview. J. Am. Coll.Nutr. 19, 549-555.

18. Kritchevsky, S.B. (2004) A review of scientific research and recommendation regarding eggs. J. Am. Coll.Nutr. 23, 596600 .

19. Krumholz, H. M., Seeman, T. E., Merrill, S. S., Mendes de Leon, C. F., Vaccarino, V., Silverman, D. I., Tsukahara, R., Ostfeld, A. M., and Berkman, L. F. (1994) Lack of association between cholesterol and coronary heart disease mortality and morbidity and all-cause mortality in persons older than 70 years. JAMA 272, 1335-1340.

20. Li, X., Su, Y., Sun, J., and Yang, Y. (2012) Chicken embryo extracts enhance spleen lymphocyte and peritoneal macrophages function. J. Ethnophamacol. 144, 255-260.

21. McNamara, D. J. (2000) The impact of egg limitations on coronary heart disease risk: do the numbers add up? J. Am. Coll. Nutr. 19, 540S-548S.

22. Moussion, C. and Girard, J, P. (2011) Dendritic cells control lymphocyte entry to lymph nodes through high endothelial venules. Nature 479, 542-546.

23. Nagaoka, S., Masaoka, M., Zhang, Q., Hasegawa, M., and Watanabe, K. (2002) Egg ovomucin attenuates hypercholesterolemia in rats and inhibits cholesterol absorption in Caco2 cells. Lipids 37, 267-272.

24. Niggemann, B., Sielaff, B., Beyer, K., Binder, C., and Wahn, U. (1999) Outcome of double-bind, placebo-controlled food challenge tests in 107 children with atopic dermatitis. Clin. Exp. Allergy 29, 91-96.
25. Noh, S. K. and Koo, S. I. (2003) Egg sphingomyelin lowers the lymphatic absorption of cholesterol and alpha-tocopherol in rats. J. Nutr. 133, 3571-3576.

26. Sampson, H. A. (2004) Update on food allergy. J. Allergy Clin. Immunol. 113, 805-819.

27. Seo, J. H., Lee, J. W., Lee, Y. S., Lee,S. Y., Kim, M. R., Yook, H. S., and Byun, M. W. (2004) Change of an egg allergen in a white layer cake containing gamma irradiated egg white. $J$. Food. Prot.6 7, 1725-1730.

28. Song, W.O. and Kerver, J. M. (2000) Nutritional contribution of eggs to American diets. J. Am. Coll. Nutr. 19, 556-562.

29. Stamler, J. and Shekelle, R. (1998) Dietary cholesterol and human coronary heart disease. Arch. Pathol. Lab. Med. 112, 1032-1040.

30. Sunwoo, H. H., Lee, E. N., Gujral, N., and Suresh, M. R. (2010) Growth inhibition of Escherichia coli $987 \mathrm{P}$ by neutralizing IgY antibodies. Open Immunol. J. 3. 1-8

31. Szepfalusi, Z., Ebner, C., Pandjaitan, R., Orlicek, F., Scheiner, O., Boltz-Nitulescu, G., Kraft, D., and Ebner, H. (1994) Egg yolk alpha-livetin (chicken serum albumin) is a crossreactive allergen in the bird-egg syndrome. J. Allergy Clin. Immunol. 93, 932-942.

32. Van der Wal, J. S., Marth, J. M., Khosla, P., Jen, K. L., and Dhurandhar, N. V. (2005) Short-term effect of eggs on satiety in overweight and obese subjects. J. Am. Coll. Nutr. 24, 510515.

33. Van der Plancken, I., Delattre, M., Indrawati, I., Van Loey, A., and Hendrickx, M. E. (2004) Kinetic study on the changes in the susceptibility of egg white proteins to enzymatic hydrolysis induced by heat and high hydrostatic pressure pretreatment. J. Agric. Food. Chem.52, 5621-5626.

34. Wallach, M. G., Webby, R. J., Islam, F., Walkden-Brown, S., Emmoth, E., Feinstein, R., and Gronvik, K. O. (2011) Crossprotection of chicken immunoglobulin $\mathrm{Y}$ antibodies against $\mathrm{H} 5 \mathrm{~N} 1$ and $\mathrm{H} 1 \mathrm{~N} 1$ viruses passively administered in mice. Clin. Vaccine Immunol. 18, 1083-1090.

35. Walsh, B. J., Barnett, D., Burley, R. W., Elliott, C., Hill, D. J., and Howden, M. E. H. (1988) New allergens from hen's egg white and egg yolk. Int. Arch. Allergy Immunol. 87, 81-86.

(Received 2013.8.2/Accepted 2013.9.9) 